\title{
Nevoid Basal Cell Carcinoma Syndrome : A Case Report
}

\author{
Yoonjung Lee', Jaehong Park², Sungchul Choi², Sooeon Lee², Kwangchul Kim¹ \\ 'Department of Pediatric Dentistry, Kyung Hee University Dental Hospital at Gangdong, \\ ${ }^{2}$ Department of Pediatric Dentistry, School of Dentistry, Kyung Hee University
}

\begin{abstract}
Nevoid basal cell carcinoma syndrome(NBCCS) is a autosomal dominant disorder, and its major manifestations are multiple basal cell carcinoma, keratocystic odontogenic tumor, rib anomalies, palmer and plantar pits, calcification of the falx cerebri. Keratocystic odontogenic tumor(KCOT) is defined as intraosseous tumor of odontogenic origin with a characteristic lining of parakeratinized stratified squamous epithelium and potential aggressive behavior. We report a case of a 3-year-old patient with nevoid basal cell carcinoma syndrome who initially presented with unilocular keratocystic odontogenic tumor in maxillary canine region. Keratocystic odontogenic tumor was treated by enucleation, and periodic follow-up check will be required for early diagnosis of additional diseases related with this syndrome.
\end{abstract}

Key words : Nevoid basal cell carcinoma syndrome, Keratocystic odontogenic tumor, Enucleation

\section{I. 서 론}

기저세포모반증후군(Nevoid basal cell carcinoma syndrome, NBCCS)은 Golrlin-Goltz 증후군으로도 알려져 있으 며 1894년에 Jarisch ${ }^{1}$ 가 처음으로 이 증후군을 가진 환자를 소 개하였고, 1960년에 Golrlin과 Goltz 가 가 증후군의 특징으로써 다발성 기저세포암, 악골의 다발성 각화낭종, 이열늑골의 3 대 주요증상을 보고하였다. 환자들마다 증상이 매우 다양하게 나 타나는데 기저세포모반증후군의 임상적, 방사선적 진단 기준에 서 적어도 2 개의 주 진단기준이 존재하거나 1 개의 주 진단 기 준과 2 개의 부 진단 기준이 존재할 때 진단할 수 있다 ${ }^{3)}$. 대개 상염색체 우성으로 유전되고 ${ }^{1)}, 9 q 22.3-q 31$ 염색체에 위치한 $\mathrm{PTCH} 1$ 에서의 변이가 증후군의 원인으로 보고되었다 ${ }^{4)}$.

기저세포모반증후군에서 호발하는 각화낭성 치성종양은 양성 의 단방성 또는 다방성으로 나타나는 치성기원의 골내종양으로
착각화된 중층 편평상피에 의해 특징적으로 이장되어 있고 공 격적이고 침습적인 성향을 갖는 것으로 정의된다. 각화낭성 치 성종양은 1956년 Phillipsen ${ }^{5)}$ 에 의해 치성 각화낭(odontogenic keratocyst)으로 보고된 이후 침습적인 성향을 띄는 종 양의 특성을 반영하여 현재는 국제보건기구(World Health Organization)에 의해 조직분류가 개정되어 양성종양의 하나 로 다루게 되었다 ${ }^{6.7)}$. 각화낭성 치성종양은 악골 어느 부위에서 도 발생할 수 있으며 하악의 후방부와 상행지부에서 가장 빈번 히 나타나지만 상악에서는 견치부위에서 흔하게 발생한당.

본 증례는 감별진단이 필요한 상악 견치부위의 단방성의 낭 종을 주소로 강동경희대학교병원 치과병원 소아치과에 내원한 환아로 조직검사를 통해 각화낭성 치성종양으로 밝혀진 후 임 상적, 방사선학적 검사를 통해 기저세포모반 증후군으로 진단 되었기에 보고하고자 한다. 


\section{II. 증례 보고}

3 세 10 개월의 여아가 내원 이틀 전부터의 발열과 좌측 협측 부위에 종창을 보였으며, 봉와직염이 의심되어 강동경희대학교 병원 소아과에 입원 후 약물치료를 하였으나 종창이 안와 하방 까지 더 심해져 본과에 의뢰 되었다. 환아는 미숙아로 태어나서 수두증의 진단을 받았었으나 최근의 검사를 통해 대두증에 가 깝다는 재진단을 받은바 있고 언어기능과 운동기능에 대한 발 달지연의 전신병력이 있었으며 외상이나 치과병력 상에는 특이 사항이 없었다. 외관상 돌출된 이마와 함몰된 중안모 및 양안 격리증의 양상을 나타내었다(Fig. 1).

구외 검사를 통해 좌측 협측 부위에서 구순부에 이르는 부위 의 종창으로 인한 안면 비대칭을 확인할 수 있었고, 구내 검사 시 상악 좌측 유견치의 순측 치은부에서 전정부에 이르는 종창 이 있었다(Fig. 2). 방사선사진을 통해 상악 좌측 유견치와 상
악 좌측 유측절치의 치근사이에 경계가 명료한 서양배 형태의 방사선 투과성의 병소와 상악 좌측 유견치의 치근과 상악 좌측 견치 치배의 변위를 확인할 수 있었다(Fig. 3, 4). 컴퓨터 단층 촬영 결과 상악 좌측 유측절치와 상악 좌측 유견치 사이의 순측 피질골의 파괴가 확인되었다(Fig. 5).

전신 마취 하에 병소는 단일 조각으로 적출되었으며 적출된 조직에 대한 조직병리학적 검사를 통해 각화낭성 치성종양으로 진단되었다(Fig. 6).

이후, 진단된 종양과 환아의 전신병력 및 외관상 특징과의 연 관성을 통해 각화낭성 치성종양이 동반된 기저세포모반증후군 이 의심되어 소아과에 의뢰 하였다. 흉부 방사선 사진을 재검토 한 결과 이열 늑골(bifid rib)이 관찰되었으며(Fig. 7), Waters 방사선 사진에서 대뇌겸의 석회화 소견은 보이지 않았다. 이에 따라 Kimonis 등 ${ }^{3)}$ 에 의한 진단 기준에서 2 개의 주요 기준과 3 개의 부가 기준을 가지므로 소아과와의 협진을 통해 본과에서

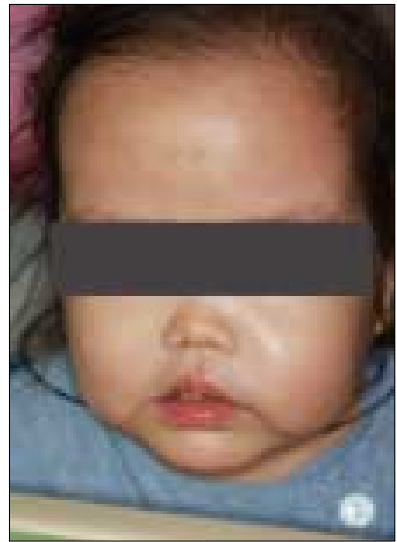

Fig. 1. Extraoral photograph showing frontal bossing and hypertelorism.

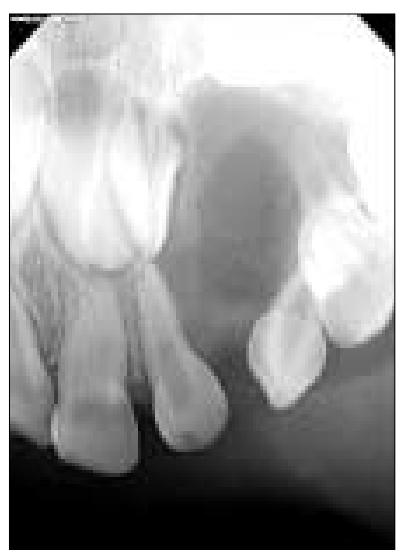

Fig. 4. Initial periapical view.

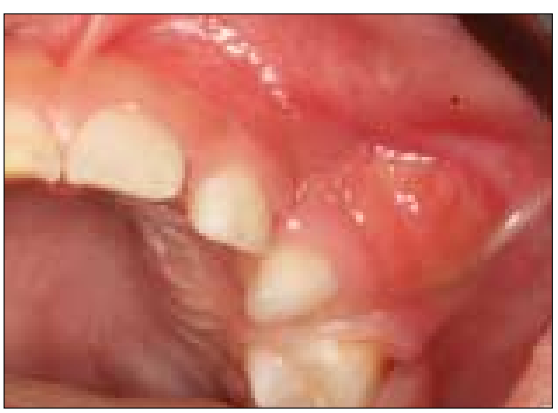

Fig. 2. Initial intraoral photograph showing a swelling on the labial vestibule of maxillary left primary canine.

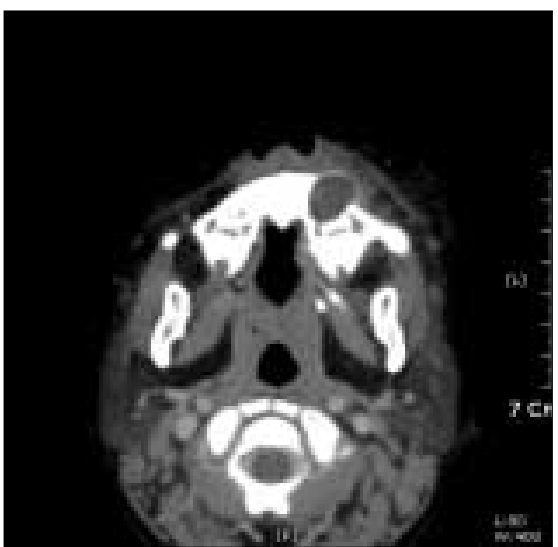

Fig. 5. Initial CT view showing cortical bone destruction on the labial side, between maxillary left primary lateral incisor and canine.

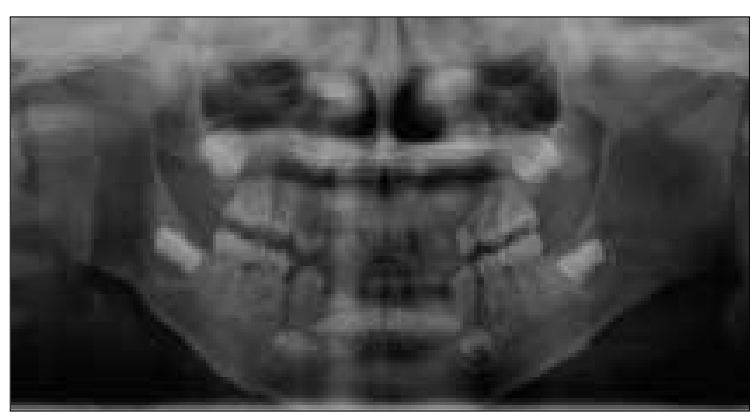

Fig. 3. Initial panoramic view showing well defined radiolucent lesion between roots of maxillary left primary lateral incisor and canine.



Fig. 6. Histologic finding $(\mathrm{x} 400)$. 


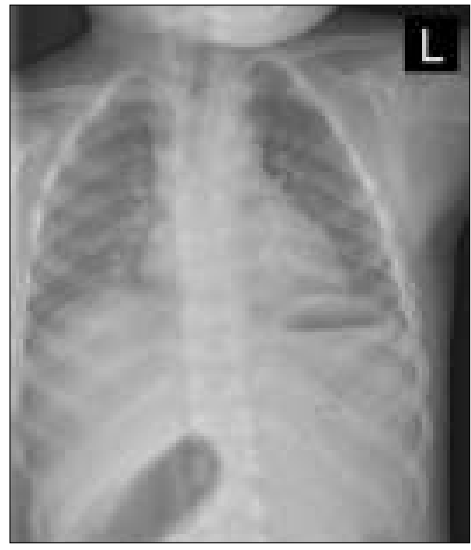

Fig. 7. Chest PA radiograph showing right fourth bifid rib.

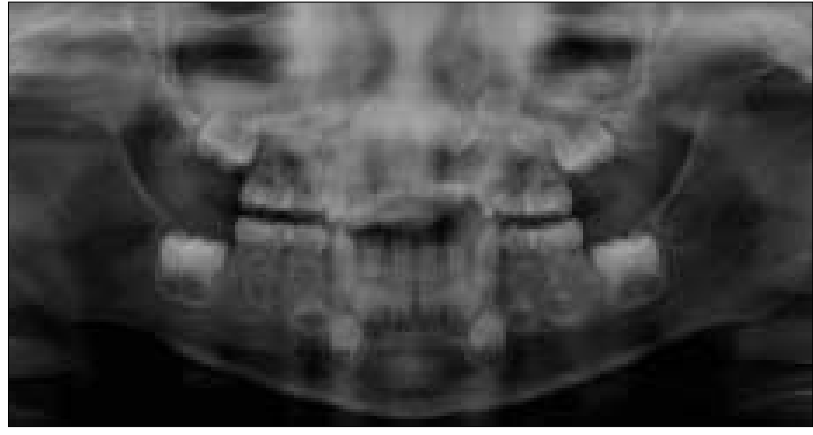

Fig. 8. Panorama view at 12-month follow-up showing a radiolucent lesion on left maxilla becoming radiopaque.

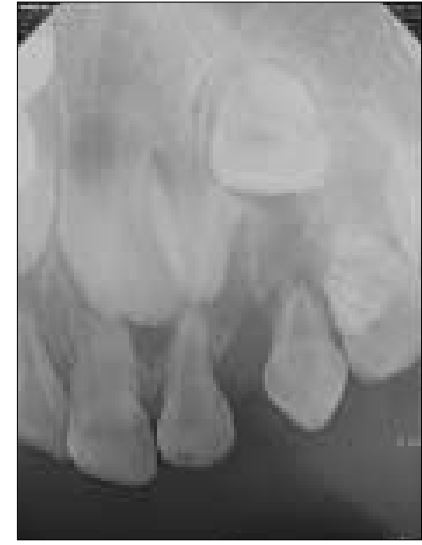

Fig. 9. Periapical view at 12-month follow-up.
기저세포모반증후군으로 진단하였다.

술 후 1 년의 방사선 검사와 컴퓨터 단층촬영을 통해 상악의 방사선 투과상은 사라진 상태였으며, 상악 좌측 유견치과 상악 좌측 측절치 치배의 변위가 완화되었고 순측 피질골은 회복되 었음을 확인할 수 있었다(Fig. 8, 9). 임상 검사에서는 상악 좌 측 유견치의 치은퇴축과 1 도 정도의 동요도가 관찰되었다(Fig. 10). 1 년의 정기검진동안 종양의 재발은 발생하지 않았고 증후 군과 관련된 추가적인 임상증상도 발생하지 않고 있다.

\section{III. 총괄 및 고찰}

기저세포모반증후군은 흔하지 않은 상염색체 우성 유전질환 으로 인종에 따라 유병률에 차이를 보이는데 한국에서 이 증후 군의 유병률은 다른 나라들에 비해 매우 낮은 것으로 보고되고 있다 ${ }^{9}$.

기저세포모반증후군은 임상적, 방사선적 소견의 종류와 발현 시기가 매우 다양하기 때문에 조기진단에 어려움이 있다. 기저 세포모반증후군의 진단 기준은 1993년에 Evans 드이에에 의해 처음으로 확립되었고, 이후 1997년에 Kimonis 등에 에 의해 조 정되었으며, 적어도 2 개의 주 진단 기준이 존재하거나 1 개의 주 진단 기준과 2 개의 부 진단 기준이 존재할 때 기저세포모반 증후군으로 진단한다(Table 1). 본 증례에서는 각화낭성 치성 종양이 먼저 확인되었고 이후 이열 늑골까지 2 개의 주요 기준 이 일치하였으며 대두증, 전두부 돌출 및 양안 격리증의 3 개의 부가 기준이 확인되어 기저세포모반증후군으로 진단되었다.

각화낭성 치성종양은 종종 증후군의 첫 번째 증상으로 나타 나 본 증례에서와 같이 증후군 진단의 계기가 될 수 있으며 기 저세포모반증후군에서의 각화낭성 치성종양이 각화낭성 치성종 양 단독으로 존재하는 경우보다 더 어린 나이에 발생하는 경향 이 있다.111. 또한 증후군과 연관된 각화낭성 치성종양은 일반적 으로 다발성이지만 2000년에 Bolbaran 등 ${ }^{12}$ 이 단발성의 증례 를 보고하기도 하였고, Lo Muzio 등1ㅡ은 어린이에서는 단지

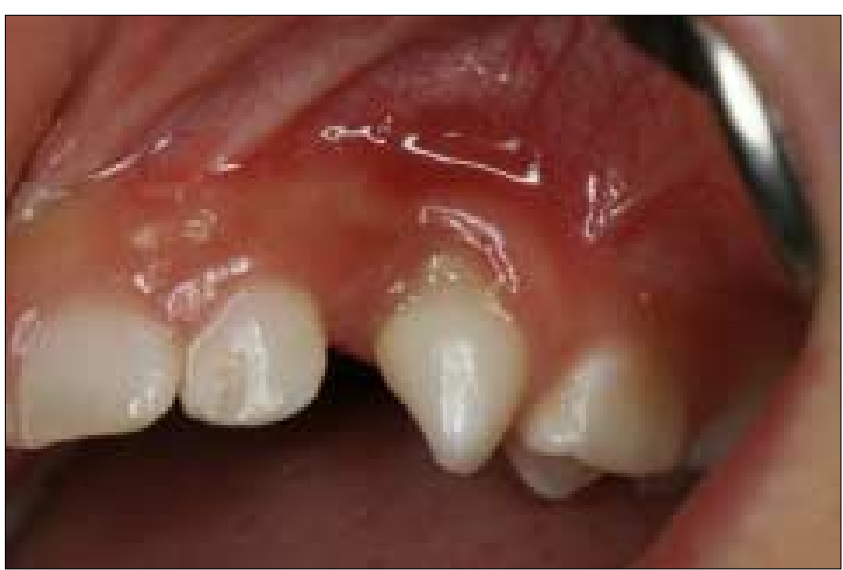

Fig. 10. Intraoral photograph at 12-month follow-up.

1 개의 각화낭성 치성종양도 기저세포모반증후군의 가능성을 나 타낼 수 있다고 하였다. 본 증례에서도 상악 견치부위에서 단방 성의 단일 종양의 형태였기 때문에 초기의 잠정적 진단 시에는 증후군을 예상하지 못하였으나 앞서 언급되었던 것처럼 특히 어린나이에서는 단방성의 종양일지라도 증후군의 가능성을 고 려하여 후속 검사가 필요할 것으로 생각된다.

본 증례에서와 같은 상악 견치 부위에서의 단방성의 각화낭 성 치성종양은 방사선 사진에서 함치성낭, 측방치주낭, 비구개 관낭, 잔류낭 등의 다른 병소들과 유사하게 보일 수 있어 감별 진단이 필요하다. 특히 통증, 부종, 삼출 등과 같은 염증성 증상 들이 동반된 경우에 더욱 임상적, 방사선적 정보만으로는 정확 한 진단이 어렵달. 각화낭성 치성종양은 다른 낭종들과 뚜렷이 구별되는 조직학적 특징을 가지므로 조직학적 검사가 진단을 위해 필수적이다.

각화낭성 치성종양의 치료법으로는 조대술, 적출술, Carnoy 용 액이나 냉동요법 등을 동반한 적출술, 변연절제술 등이 있다 ${ }^{13.14)}$. 본 증례에서는 환아의 나이가 매우 어린 점을 고려하여 보존적 
Table 1. Diagnotic criteria in NBCCS

$\begin{array}{ll}\text { Major criteria } & \text { Multiple( }>2) \text { BCCs or 1 younger than } 20 \text { years } \\ & \text { Odontogenic keratocysts of the jaws proven by histopathology } \\ & \text { Three or more palmer or plantar pits } \\ & \text { Bilamellar calcification of the falx cerebri } \\ & \text { Bifid, fused or markedly splayed ribs } \\ & \text { First-degree relatives with NBCCs } \\ & \text { Macrocephaly after adjustment for height } \\ \text { Minor criteria } & \text { Congenital malformation: cleft lip or palate, frontal bossing. "coarse face", moderate or severe hypertelorism } \\ & \text { Other skeletal abnormalities: Sprengel defomity, marked pectus deformity, marked syndactyly of the digits } \\ & \text { Radiological abnomalities: bridging of sella turcica, vertebral anomalies, such as hemivertebrae, fusion or elongation of the } \\ & \text { vertebral bodies, modeling defecta of the hands and feet, or flame-shaped lucencies of the hands or feet } \\ & \text { Ovarian fibroma } \\ & \text { Medulloblastoma }\end{array}$

Kimonis et al. : Am J Med Genet, 69:299-308, 1997.

인 치료법인 적출술로 치료를 진행하였다.

기저세포모반증후군에서의 각화낭성 치성종양은 상피 기저세 포층 안에 새로운 낭을 발생시킬 수 있는 유전적 성향으로 인하 여 증후군과 관련 없는 각화낭성 치성종양 $(28 \%)$ 과 비교할 때 증후군에서의 각화낭성 치성종양은 $60 \%$ 의 높은 재발 잠재성을 가진다 ${ }^{15)}$. 따라서 술 후 첫 5 년은 매년, 그 이후에는 2 년마다의 정기적인 검진이 추천된다 ${ }^{16)}$

기저세포모반증후군의 주요 소견 중에서 늑골 이상은 기저세 포모반증후군 환자의 $30 \sim 60 \%$ 에서 보고되고 있으며 본 증례 에서 나타난 것과 같이 이열늑골이 가장 흔하게 관찰된다 ${ }^{15)}$. 이 외에 기저세포암, 손과 발바닥의 소와, 대뇌겸의 석회화는 본 증례에서 관찰되지 않았다. 그러나 기저세포암의 경우 영아기 에 나타나는 경우도 있지만 대부분 사춘기에서 35세 사이에 발 생하고 ${ }^{15)}$, 손과 발바닥의 소와는 10세 무렵에 환아의 30 65\% 정도에서 나타나며 연령이 증가할수록 더 많이 나타난다 ${ }^{17)}$. 또 한 초기병소가 관찰된 후 23 년이 지나 피부, 골격 등 증후군의 다른 증상이 추가로 나타난 보고도 있었다 ${ }^{18)}$. 따라서 환아의 나 이가 만 3세로 매우 어린 것을 고려 할 때 현재 관찰되지 않은 증후군의 다른 소견들이 이후에 나타날 가능성이 매우 높을 것 으로 생각된다. 특히 주로 소아에서 호발하는 악성 침습적 배아 성 뇌종양인 수모세포종(medulloblastoma)이 발병할 가능성 이 있으므로 이런 질병들에 대한 조기진단을 위해 정기적인 검 진과 추적 검사가 매우 중요하고 예방을 위한 교육도 필요할 것 이다. 후속검진을 위한 지침으로는 첫째, 신경학적 검사는 연 2 회 시행해야하며, 둘째, 1 7세 사이에 매년 뇌의 MRI 촬영, 셋째, 8세경부터 시작해서 12 18개월 마다 파노라마 촬영, 넷 째, 증상에 따라 매년 피부 검사와 심장 검사를 시행하는 것이 다 ${ }^{19)}$.

현재 환아는 병소의 재발과 증후군과 관련된 추가적인 임상 증상에 대한 추적 검사를 진행 중이며, 유전성 질환임을 고려하 여 가족들에 대한 유전자 검사 및 상담이 예정되어 있다.

본 증례는 이전에 보고되었던 기저세포모반증후군의 증례들
과 비교하여 환아가 매우 어렸다는 점과 일반적으로는 증후군 과의 연관성을 놓치기 쉬운 단방성의 각화낭성 치성종양을 계 기로 증후군으로 진단되었다는 점에 주목 할 수 있을 것이다. 기저세포모반증후군은 치과의사에 의해 처음 발견되는 경우가 많고, 조기 진단이 중요하다는 점에서 이 질환의 임상적, 방사 선적인 특징들에 대한 임상가의 관심이 필요할 것이다.

$$
\text { IV. 요 약 }
$$

상악 견치부위의 단방성의 낭종을 주소로 강동 경희대학교 치과병원 소아치과에 내원한 3 세 10 개월의 환아가 전신마취 하 에 적출술을 시행 받고 조직검사를 통해 각화낭성 치성종양으 로 진단받은 것을 계기로 기저세포모반증후군으로 진단되었다. 단방성의 각화낭성 치성종양은 감별진단이 어려우므로 반드시 조직학적 검사가 진단을 위해 필요하고, 각화낭성 치성 종양의 재발여부와 기저세포모반증후군과 관련된 추가적인 질환들의 조기진단을 위하여 정기적인 검진이 중요하다.

\section{References}

1. Jarish W : Zur lehre von den autgeschwulsten. Archiv Jur Dermatologic und Syphilogic, 28: 163222, 1894.

2. Gorlin RJ, Goltz RW : Multiple nevoid basal cell epithelioma, jaw cysts and bifid rib syndrome. New Engl J Med, 262:908-12, 1960.

3. Kimonis VE, Goldstein AM, Bale SJ, et al. : Clinical manifestations in 105 persons with nevoid basal cell carcinoma syndrome. Am J Med Genet, 69:299-308, 1997.

4. Cohen MM Jr : Nevoid basal cell carcinoma syndrome:molecular biology and new hypotheses. Int $J$ 
of Oral Maxillofac Surg, 28:216-223, 1999.

5. Philipsen HP : Keratocysts in the jaw. Tandlaegeblader, 60:963-80, 1956.

6. Gupta A, Rai B, Nair NA, Bhut MK : Keratocystic odontogenic tumor with impacted maxillary third molar involving the right maxillary antrum: an unusual case report. Indian J Dent Res, 22:157-60, 2011.

7. Madras J, Lapointe H: Keratocystic odontogenic tumour: reclassification of the odontogenic keratocyst from cyst to tumour. J Can Dent Assoc, 74: 165-165, 2008

8. Ali M, Baughman RA : Maxillary odontogenic keratocyst: a common and serious clinical misdiagnosis. J Am Dent Assoc, 134:877-83, 2003.

9. Ahn SG, Lim YS, Yoon JH, et al. : Nevoid basal cell carcinoma syndrome: a retrospective analysis of 33 affected Korean individuals. Int $J$ Oral Maxillofac Surg, 33:458-462, 2004

10. Evans DGR, Ladusans EJ, Farndon PA, et al. : Complication of nevoid basal cell carcinoma syndrome: results of a population based study. $J$ Med Genet, 30:460-4, 1993.

11. Lo Muzio L. Nocini P, Procaccini M, et al. : Early diagnosis of nevoid basal cell carcinoma syndrome. $J$ Am Dent Assoc, 130: 669-74, 1999

12. Bolbaran V, Martinez B, Rojas R : Odontogenic ker- atocysts. A retrospective study of 285 cases. (II. Histopathological aspects.) Med Oral, 5:338-44, 2000.

13. Stoelinga PJ : Long-term follow-up on keratocysts treated according to a defined protocol. Int $J$ Oral Maxillofac Surg, 30:14-25, 2001.

14. Blanas N, Freund B, Schwartz M, Furst IM : Systemic review of the treatment and prognosis of the odontogenic keratocyst. Oral Surg Oral Med Oral Pathol Oral Radiol Endod, 90:553-8, 2000.

15. Lo Muzio L : Nevoid basal cell carcinoma syndrome (Gorlin syndrome). Orphanet $J$ Rare Dis, 3:32, 2008.

16. Manfredi M, Vescovi P, Bonanini M, Porter S : Nevoid basal cell carcinoma syndrome: a review of the literature. Int J Oral Maxillofac Surg, 33:11724, 2004.

17. Gutierrez MM, Mora RG : Nevoid basal-cell carcinoma. J Am Acad Dermatol, 15:1023-30, 1986.

18. Woolgar JA, Rippin JW, Browne RM : The odontogenic keratocyst and its occurance in the nevoid basal cell carcinoma syndrome. Oral Surd Oral Med Oral Pathol, 64:727-730, 1987.

19. Kim HM, Lee CH, Kim SK, Sung TJ : Basal cell nevus syndrome (Gorlin syndrome) confirmed by PTCH mutations and deletions. Korean J Pediatr, 50:789-793, 2007. 
국문초록

\author{
기저세포모반증후군 : 증례 보고 \\ 이윤정 ${ }^{1} \cdot$ 박재홍 $^{2} \cdot$ 최성철 $^{2} \cdot$ 이수언 $^{2} \cdot$ 김광철 $^{1}$ \\ 1강동경희대학교병원 치과병원 소아치과, \\ 2 경희대학교 치과대학 소아치과학교실
}

기저세포모반증후군은 상염색체 우성의 유전 질환이며 주요소견으로는 다발성 기저세포암, 악골의 다발성 각화낭종, 늑골 이상, 손과 발바닥의 소와, 대뇌겸의 석회화 등이 있다. 기저세포모반증후군에서 호발 하는 각화낭성 치성종양은 치성기원의 골내종양으로 착각화된 중층 편평상피에 의해 특징적으로 이장되어 있고 공격적이고 침습적인 성향을 갖는 것으로 정의된다. 본 증례는 감별진단이 필요한 상악 견치부위의 단방성의 낭종을 주소로 내원한 환아가 조직검사를 통해 각화낭성 치성종양으 로 밝혀진 후 임상적, 방사선학적 검사를 통해 기저세포모반 증후군으로 진단된 경우이다. 종양은 적출술로 치료되었고 증후 군과 연관된 추가적인 질환들의 조기진단을 위해 정기적인 검진이 필요할 것이다.

주요어: 기저세포모반증후군, 각화낭성 치성종양, 적출술 